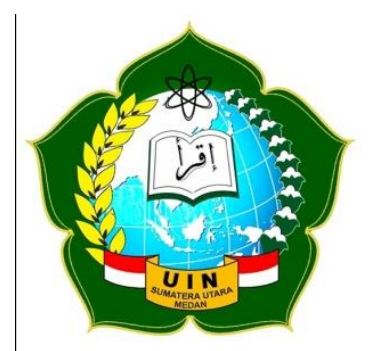

VISION JOURNAL

http://jurnaltarbiyah.uinsu.ac.id/vision

\title{
PICTURE WORDS INDUCTIVE MODEL FOR YOUNG LEARNER IN IMPROVING ENGLISH VOCABULARY FOR INDONESIAN STUDENTS AT SD SWASTA PELANGI MEDAN
}

\author{
Ernita Daulay \\ Department of English Education, UINSU \\ Email: ernitadaulay@uinsu.ac.id
}

\begin{tabular}{|l|l|}
\hline Keywords & Abstract \\
\hline $\begin{array}{l}\text { Keywords: Model of Teaching, } \\
\text { Vocabulary }\end{array}$ & $\begin{array}{l}\text { The Picture word inductive is an inquiry-oriented language } \\
\text { arts strategy that uses pictures containing familiar objects and } \\
\text { actions to elicit words from children's listening and speaking } \\
\text { vocabularies. This strategy leads the students to identify each } \\
\text { object in a picture that they will describe. The aim of this } \\
\text { study was to find out the effectiveness of Picture Word } \\
\text { Inductive Model in improvement vocabulary skills' for } \\
\text { Indonesian students at SD Swasta Pelangi Medan. The } \\
\text { population of this research is the Second year students at SD } \\
\text { Swasta Pelangi. The number of sample is 28 students selected } \\
\text { by using cluster random sampling technique. Based on the } \\
\text { result of this research, the writer suggest that Picture Word } \\
\text { Inductive Model may be used as alternative media in teaching } \\
\text { vocabulary, in order that the students can more understand } \\
\text { and interested in learning activity especially in learning of } \\
\text { English. }\end{array}$ \\
\hline
\end{tabular}

Faculty of Tarbiyah and Teacher Training, 1st Floor Jalan Willem Iskandar Psr V Medan, 20731

Telp. 061- 6622925 - Fax. $061-6615685$

\section{INTRODUCTION}

Every social group has different language, for example, a group of people who were born and live in England, speak English as their native language, and the group of people 
who were born and live in Indonesia, speak Indonesian. In Indonesia, English is considered as a foreign language and becomes one of the compulsory subject in Junior High School and Senior High School. English subject in the Kurikulum Tingkat Satuan Pendidikan is divided into four skills such as reading, writing, speaking, and listening. According to Hiebert and Kamil (2005), vocabulary is the knowledge of the meanings of words. The students who want to use a language, need to know what to say the word in the target language. In other words, without vocabulary, nothing can be conveyed.

Vocabulary is one linguistic feature which influences the communicative competence. Nation (2011) states that in English as a second language (ESL) and English as a foreign language (EFL) learning vocabulary items plays a vital role in all language skills, listening, speaking, reading, and writing. It means that the students who have good vocabulary will be able to master the four language skills. Besides that, by mastering the vocabulary, the students' achievement in language components will also be improved.

The classic definition of teaching is the design and creation of environments. Students learn by interacting with those environment and they study how to learn (Dewy: 1916). A model of teaching can be defined as the depiction of teaching and learning environment, including the behaviour of teachers and students while the lesson is presented through that model. Models of teaching enable the students to engage in robust cognitive and social task and teach the student how to use them productively. Models of teaching are the specific instructional plans which are designed according to the concerned learning theories

Models of teaching and learning are critical pieces to instructional planning and delivery because they help educators: 1) Develop highly tuned and the choices of learning activities recently become the most important concern to make student motivation and achievement better.; 2) Allow them to reach larger numbers for students more effectively; 3) Create either more uniform, or varied, or effective instructional events, guided by targeted subjects, content, or processes; 4) Understand curricular foci better, especially as different models can be matched specifically to both learning outcomes and/or targeted learning populations; 5) Gain needed insights into why some methods work with some learners, while others do not; 6) Radically modify or redesign existing methods of teaching and instructional delivery so that emerging or altered instructional techniques may better meet the needs of today's students (Leslie Owen Wilson : 2017). To improve students' vocabulary skill the teacher needs appropriate strategies to teach them. The teacher should chooseintersting appropriate strategy. By using a suitable strategy, the students will be more interested in 
learning English. An appropriate strategy for teaching vocabulary isvery important because it determinesthe result of teaching vocabulary. An appropriate technique can improve students' vocabulary mastery.

There are many strategy that are appropriate in teaching vocabulary such as: word mapping, word wall, vocabulary journals and also picture words inductive (Rohma: 2017). Picture word inductive is a strategy which uses the advantage of the picture as the learning media in teaching and learning process. Picture wordinductive is a process of teaching language involving basic moves from identifying the pictures, looking for new words, hearing the new word pronounced correctly, and watching the teacher model how to use the vocabulary on a variety of levels. Thus, this is an effective strategy for all ages of learners for learning a second language because students have an opportunity to learn from authentic materials (McDonald, 2010).

Picture Word Inductive Model was chosen as a model to solve the problem. It helps students to improve English vocabulary in speaking skills. In this case the writer will take picture word inductive in improve vocabulary skills, because through picture words inductive students can see person, place and thing directly. The use of picture are more efficient and practice than word, they easier to recall and remember than words, further more they expose real life situation although it happen a long time ago. The researcher did not only interview the English teacher but also observed the situation in the class. Teaching activity is not easy for teachers as most teachers seem to have difficulty in choosing a strategy to teach English, especially vocabulary. They commonly use a conventional strategy such as writing down the list of vocabulary and asking the students to memorize the word. In pedagogical competency, the teacher must be able to decide the best strategy and media that will be used in the teaching-learning process.

Vocabulary learning is often perceived as boring by learners, especially for those who grew up in the digital age (Turgut \& Irgin, 2009). And in for some people who have experience in learning a foreign language know that vocabulary is always one of the major problems in language learning no matter one is at the beginning or at the end of language learning. (Barani, Mazandarani, \& Rezaie, 2010). Therefore, there need to be some promising alternatives in facilitating the vocabulary learning.

The Application of Picture Word Inductive Model to improve vocabulary skills, can be a cycle or a series for the teaching process. The teacher should do some activity that as follow are: 
a) Select a picture.

b) Ask the student to identify what they see in the picture.

c) Label the picture parts identified. (Draw a line from the identified objector area, say the word, write the word; ask students to spell the word aloud and then to pronounce it).

d) Read and review the picture word chart aloud.

e) Ask students to read the words (using the lines on the chart if necessa54aaaaaary) and to classify the words into a variety of groups. Identify common concepts (e.g., beginning consonants, rhyming words) to emphasize with the whole class.

f) Read and review the picture word chart (say the word, spell it, say it again)

g) Add words, if desired, to the picture word chart and to the word banks.

h) Lead students into creating a title for the picture word chart. Ask students to think about the information on the chart and what they want to say about it.

Vocabulary learning is effective when it entails active engagement that goes beyond definitional knowledge. "When children 'know' a word, they not only know the word's definition and its logical relationship with other words, they also know how the word functions in different contexts." Stahl and Kapinus (2001). Picture word inductive strategy is also exciting and interesting. It could motivate the students in vocabulary teaching and learning process. They were very enthusiastic during the teaching and learning process. So, it can be concluded that picture word inductivestrategy could improve students' vocabulary by attracting students in attending the lesson.

In foreign language learning, there should be a certain method and technique required by a teacher in efforts to achieve the teaching and learning target. Furthermore, to achieve the learning target during learning process, a teacher has to be capable of finding a way out or teaching technique and media how to attract and make the students enjoy learning as it is expected. If the teaching technique and media correspond with the material to teach and the learner's need, it will make the teacher easy to transfer the material to teach andwith a pleasure the students will also be capable of accepting it without any burden. Therefore, there are quite a lot of media and teaching techniques which can be used depending on the teacher's creativity in delivering the material to teach and the teaching target to achieve. However, there are several media and teaching techniques which are very popular in English language teaching, such as picture word inductive, flow chart, role-play, story-telling, student-centered learning, discussion, games and songs (Suyanto, Kasihani: 1999). 
In foreign language learning, there should be a certain method and technique required by a teacher in efforts to achieve the teaching and learning target. Rivers, Wilga M ( 1971) said that there were several teaching methods, especially in foreign language teaching. They were Grammar-translation Method, Direct Method, Reading Method andAudio-lingual Method. Furthermore, to achieve the learning target during learning process, a teacher has to be capable of finding a way out or teaching technique and media how to attract and make his students enjoy learning as it is expected. If the teaching technique and media correspond with the material to teach and the learner's need, it will make the teacher easy to transfer the material to teach andwith a pleasure the students will also be capable of accepting it without any burden. Therefore, there are quite a lot of media and teaching techniques which can be used depending on the teacher's creativity in delivering the material to teach and the teaching target to achieve. However, there are several media and teaching techniques which are very popular in English language teaching, such as flow chart, role-play, storytelling, student-centered learning, discussion, games and songs(Suyanto, Kasihani: 1999).

\section{Models of Teaching}

Joyce \& Weil (2014) defines a model of teaching is a description of a learning environment, including our behavior as teachers when that model is used. Thus Models are prescriptive teaching strategies which help to realize specific instructional goals. Models of teaching are really models of learning. It helps students to acquire information, ideas, skills, value, way of thinking and means of expressing themselves. Hence models of teaching train the student on how to learn. In fact the most important long term outcome of instruction may be the student's increased capabilities to learn more easily and effectively in the future. Hence the main aim of models of teaching is to create powerful learners. Pictures Word Inductive Model uses inquiry-oriented learning strategies that enable students to involve actively in the learning process. According to Coffman (2009) "inquiry learning emphasis on active engagement in the learning process to develop and build students understanding through questioning and discovering information." In the inquiry learning, the teacher guided the students to involve actively in learning process by guiding them to discovering and understanding the information. Pictures Word Inductive Model is one of the writing strategies from Calhoun that applied in pre writing process. The use of Pictures Word Inductive Model emphasized more on how students recognized the words by looking at the pictures that teacher provided and by using those words and pictures students make the titles. Picture word 
inductive improved students English vocabulary and students able to compose meaningful English paragraph. As well as students motivation toward learning English (Feng, 2011). Picture word inductive is used by English teachers to get better scores and as an alternative technique for teaching writing skills (Suraya, 2017). Using Picture word inductive students can benefit from teacher modeling of keywords and concepts. With practice, they can learn to make sentences and paragraphs related to the subject. Picture word inductive can help the teacher to provide curricular and instructional balance better by focusing the lesson to arrange and understand the subject and using it can help students make sentences using new words in the picture and also try to create an understanding of the connection of reading or speaking Joyce \& Weil (2014) define the following are the chief characteristics of a good teaching model:

- Each model has built up based on particular learning theory

- Creation of congenial learning environment in the classroom

- Effective interaction between the teacher and students

- Planned use of appropriate strategies

- Teaching process are systematically, sequentially and logically arranged

- Clear and specified roles for teachers and students

- Large scope for supporting material

- Ensure active participation of entire students in the class

- It raises the students' level of aspiration, motivation and interest in learning

- Every model foster and strengthen the cognitive structure of the student

Bruce Joyce and Marsha Weil describe a Model of Teaching as a plan or pattern that can be used to shape curricula, to design instructional materials and to guide instruction in the classroom and other settings. Thus teaching models are just instructional designs. They describe the process and producing particular environmental situations which cause the student to interact in such a way that specific change occurs in his behaviour. Models of teaching are designed for specific purposes-the teaching of information concepts, ways of thinking, the study of social values and so on-by asking students to engage in particular cognitive and social tasks. Some models centre on delivery by the instructor while others develop as the learners respond to tasks and the student is regarded as a partner in the educational enterprise.

The picture word inductive is an inquiry-oriented language arts strategy that uses pictures containing familiar objects and actions to elicit words from children's listening and 
speaking vocabularies Picture word inductive is used with classes, small groups, and individuals to lead them into inquiring about words, adding words to their sight-reading and speaking vocabularies. Vocabulary learning is often perceived as boring by learners, especially for those who grew up in the digital age (Turgut \& Irgin, 2009). And in for some people who have experience in learning a foreign language know that vocabulary is always one of the major problems in language learning no matter one is at the beginning or at the end of language learning. (Barani, Mazandarani, \& Rezaie, 2010). Therefore, there need to be some promising alternatives in facilitating the vocabulary learning. In order to teach students how to learn new vocabulary, teachers need to draw on a variety of teaching strategies in accordance with different vocabulary learning techniques (Ghaedi \& Shahrokhi, 2016). Young learners are quick to learn vocabulary, slower to learn structures because words have tangible, immediate meanings. The children should meet and use the words in relevant contexts in order to fix them in their mind.

\section{English Young Learner for Indonesian Students}

Teaching English to Young Learners is not a walk on the park in Indonesia. The inconsistency of Indonesia Ministry of education policy of whether important or not to include English as either compulsory or local content object in primary school curriculum has been recently the real issue among educational stakeholders across the country. The latest curriculum (2013) stated that English is not included both as a compulsory and a local content object. It actually has controversially been a cancellation to the previous issued policy that proposed English as a local content in primary school curriculum in Indonesia (Permendiknas, 2007). Out of the dilemmatic phenomenon, some primary schools across the country still provide English as a lesson taught. Language proficiency constitutes the foundation confidence of non-native speakers and English teachers. Language competence has been at the most essential characteristic of a good teacher.

Young learners are different compared to teaching English to adults or young adults learners; they are more enthusiastic in the classrooms. In learning a new language, children have no awareness on grammatical mistakes and less embarrassed to talk and they also tend to speak like native due to their lack inhibition (Cameron, 2001). Teachers who deal with young learners must have competence both professional competence and pedagogical competence. Working with young learners gives opportunities for language teachers to develop what the learners have already had. They, young learners, do not come to the class of 
language empty-handed; they have already had well-established instincts, skills and characteristics which help them to learn another language. The teacher is inevitably the key element for the success of the teaching end learning process in the classroom. As an International language, English is taught and learnt by almost all of the people in the world. In Indonesia for example, English has been introduced since the learners are studying at the elementary school. Even many of the kindergarten schools too, have already introduced this language to their students. However, we cannot deny that teaching foreign language is not such an easy thing due to the fact thatmany of the learners are not capable of speaking English very well although they have been learning it for more than ten years. In line with this problem, this study aims at providing a solution by offering one teaching technique which seems to make the learners (especially young learners) enjoy learning through picture word. Furthermore, young learners really enjoyed learning English vocabulary and speaking with highly motivating.

Young learners are like sponges, they soak up everything we say and how we say it. There has been a growing awareness acknowledging that teaching English to young learners is not as simple as we once thought. It is not a matter of teaching a list of simple vocabulary. It needs optimal condition and requirements that would enable young learners to further their learning, and eventually the aim of teaching English to young learners would be achieved. Some requirements that need to be consider are the curriculum, teacher competency, media and method used. In Indonesia, interest in teaching English to young learners has been steadily growing in recent years. Many parents believe that by studying English from early stage, their children will get a better future. They believe that by introducing English to their children as early as possible, it will bring their children to have a better carrier.

\section{English Vocabulary}

A vocabulary is a set of familiar words within a person's language. A vocabulary, usually developed with age, serves as a useful and fundamental tool for communication and acquiring knowledge. Acquiring an extensive vocabulary is one of the largest challenges in learning a second language (Brysbaert M, Stevens M, Mandera P and Keuleers E : 2016). Vocabulary is commonly defined as "all the words known and used by a particular person" (Knowing a word, however, is not as simple as merely being able to recognize or use it. There are several aspects of word knowledge that are used to measure word knowledge.Teaching English vocabulary to young learners refers to a more specialized 
area of teaching English which deal with younger students. It is totally different from teaching adult. Words can be defined in various ways, and estimates of vocabulary size differ depending on the definition used. The most common definition is that of a lemma (the uninflected or dictionary form; this includes walk, but not walks, walked or walking). Most of the time lemmas do not include proper nouns (names of people, places, companies, etc).

Another definition often used in research of vocabulary size is that of word family. These are all the words that can be derived from a ground word (e.g., the words effortless, effortlessly, effortful, effortfully are all part of the word family effort). Estimates of vocabulary size range from as high as 200 thousand to as low as 10 thousand, depending on the definition used (Brysbaert M, Stevens M, Mandera P and Keuleers E : 2016). When teaching young learners we constantly have to keep in mind the fact that what we have in front of us is a mixed class with varied abilities, expectations, motivation level, knowledge and last but not least, different learning styles. Teacher teaches the vocabulary by giving list of vocabulary or translates the difficult vocabulary that the students unknown. In that condition, the students know the new vocabulary, but they easily forget the vocabulary later. They just know the new vocabulary; they do not understand, master or memorize it. This case makes the students have the low vocabulary mastery. Teaching vocabulary is not easy for teacher, but the students usually get bored of learning this subject. That is why the teacher are demanded to use the model which is appropriate with the students need to achieve the good criteria of vocabulary learning, so that the students will enjoy and understand the learning process well. Learning vocabulary at Primary School can be done through many ways, such as: picture, guessing, reading, game, etc. In this case the researcher will take picture in teaching vocabulary, because through picture the students can see person, place, and thing directly. The uses of picture are more efficient and practice than word. They easier to recall and remember than words, further more they expose real life situation although it happen a long time ago.

The importance of vocabulary instruction in students' reading achievement has been acknowledged for over years. The recognition of vocabulary as a crucial component of second language knowledge and skills has led to the investigation of different strategies and techniques of vocabulary instruction in classrooms and their effects on the learning and retention of vocabulary items (Emirmustafaoğlu \& Gökmen, 2015). Therefore, since most vocabulary distinctions develop among individuals before third grade, at which point a significant disparity exists in the pace of word acquisition Vocabulary is the backbone of any 
language. Without extensive vocabulary knowledge, even those who show mastery of grammar might experience the failure to communicate (Tosun, 2015). It is essential to begin building vocabulary knowledge when children are young.

Rakchanok (2014) states that vocabulary learning plays an important role in language teaching especially in the context where English is taught as a foreign language. Vocabulary mastery can support student"es listening and reading ability to understand text they are listening and reading. Vocabulary mastery can also support studentes writing and speaking ability to communicate their ideas in written and spoken form. With the limited vocabulary the students will have the difficulties in learning and understanding the foreign language. When the students do not know the ways to increase their vocabulary they will lose their interest in learning foreign language, because they cannot understand the foreign language words. For this reason it is very important for students to build up large store of vocabulary and to have rich vocabulary. Knowing that vocabulary is an important aspect, it should be taught to the students to make them master the vocabulary as many as possible. During its infancy, young learner instinctively builds a vocabulary. The results in a wide range of vocabulary by age five or six years old, when an English vocabulary child will have learned about 1500 words. Eglish Vocabulary grows throughout our entire life. Between the ages of 20 years old, people learn some 6,000 more lemmas, or one every other day (Joan H. Lee:2011).) An average 20 years old knows 42,000 words coming from 11,100 word families. People expand their English vocabularies by e.g. reading, picture word, playing word games, and participating in vocabulary related programs. Exposure to traditional print media teaches correct spelling and vocabulary, while exposure to text messaging leads to more relaxed word acceptability constraints.

\section{METHODOLOGY}

Quantitative data consists of numbers that are obtained by using structured and validated data-collection instruments and statistically analyzed. The findings should be generalizable and thus can be applied to other populations, being able to look at cause and effect as well as making predictions (Leung, 2015). Data is often generated by means of surveys, interviews with close-ended questions and experiments in a controlled environment in order to isolate causal effects (Kelley et al., 2003).Quantitative analysis was carried out to address the research questions. This method was chosen due to its objective nature in finding the answer for this experimental study. In addition, the quasi experimental design was 
considered appropriate as the framework design for this study.

Samples are ideally selected in a way that allows generalizing the study's results to the population as a whole, thus achieving external validity (Bryman \& Bell, 2007). As the composition of a quantitative study's participants is crucial for the quality of the results, there are a number of clearly structured varieties of sampling. Quantitative research prefers a probability sampling approach, with its sub-forms of random sampling, stratified sampling, systematic sampling, and cluster random sampling or a combination of these (Center for Innovation in Research and Teaching, 2017). The sample of participants consists of 28 second graders of elementary school students. All participants were eight, or nine years old. There were two groups of participants, an experimental group $(n=14)$ who received the intervention, and a control group $(n=14)$ who received typical classroom instruction, without the intervention. To assess students' vocabulary knowledge, a researcher-generated assessment was administered prior to intervention (pretest) and immediately following intervention (posttest). This assessment, consisting of 10 vocabulary terms, targeted some of the vocabulary expected to be suggested by students in the course of the project. According to Best \& Khan (2006) "The experimental group is exposed to influence of the factor under consideration; the control group is not where both experimental group and control group received pre-test and post-test". Moreover, experimental group received the treatment and control group did not receive the treatment. The design of this study is the pretest-posttest non-equivalent group design. Best \& Kahn (2006) stated "This design is often used in classroom experiments when experimental and control groups are such naturally assembled group as intact classes, which may be similar."

\section{RESULT AND DISCUSSION}

Models of teaching are very effective teaching strategies which are meant for transacting specific topic to students. The nature of the topic, presentation method and classroom environment will direct the teacher that what model of teaching s/he has to select for teaching the concerned topic. However the teachers and student teachers should be well aware on the concept and various models of teaching. Hence they can implement the models of teaching in their professional life and make wonder in their classroom interactions. During instruction with the picture word inductive, a study based method of vocabulary instruction that connects reading and writing, students were shown a picture and were asked to identify items in the pictures. The use of picture word inductive emphasized more on how students 
recognized the words by looking at the pictures teacher provided. The teacher can use the result of the study as a feedback on teaching activities and they will increase their performance in teaching program well. This study also gives contribution to the English teacher in the use of picture word inductive as a vocabulary teaching model to improve studentes vocabulary, and also to improve the result of teaching vocabulary.

Teachers are essential factors in education. High quality teachers would produce high quality students. According to research, most teachers teaching English to young learners in Indonesia are not qualified in term of professional and pedagogical competence. This reality should be seriously considered as a main holdback in Indonesia educational system. It is important to all stake holders of teaching English to young learners to get involved actively in promoting teachers' quality both professionally and pedagogically to produce students with high quality. Through the result of the study, the quality of the teachers of English at SD Swasta Pelangi Medan both pedagogical competence and English proficiency is considered low. The factors that might influence this reality are among others the lack trainings followed by those teachers in teaching young learners and English trainings, the teachers' background knowledge which is mostly not English, and lack proficiency of English. The writer concluded that the implementation of Picture Word Inductive Model could improving English vocabulary for young learner. Based on students' opinion, Picture word inductive model is also exciting and interesting. It could motivate the students in English vocabulary teaching and learning process. They were very enjoying during the teaching and learning process. So, it can be concluded that Picture Word Inductive Model could improving English vocabulary for young learners by attracting students in attending the lesson. Picture word appears to be an effective instructional tool for classroom teachers to use in facilitating English vocabulary. During instruction with the picture word inductive, the writer based method of English vocabulary instruction that connects reading and speaking, The teacher was shown a picture and asked to identify items in the picture. This process essentially created a picture-word dictionary which the students could employ to connect words with corresponding pictures.

\section{REFERENCES}

Barani, G., Mazandarani, O., \& Rezaie, S. H. S. (2010). The Effect Of Application Of Picture Into Picture Audio- Visual Aids On Vocabulary Learning Of Young Iranian ELF 
Learners. Procedia - Social and Behavioral Sciences, 2(2), 5362- 5369. https://doi.org/10.1016/j.sbspro.2010.03.874

Best, J. W., \& Kahn, J. V. (2006). Research In Education (10th ed.). USA: Pearson

Bryman, A. \& Bell, E. (2007). Business Research Methods. New York: Oxford University Press.

Brysbaert M, Stevens M, Mandera P and Keuleers E (2016). How Many Words Do We Know? Practical Estimates of Vocabulary Size Dependent on Word Definition, the Degree of Language Input and the Participant's Age. Front. Psychol. 7:1116. doi: 10.3389/fpsyg.2016.01116.

Cameron, L. (2001). Teaching English to Young Learners. New York, NY: Cambridge University Press

Coffman, T. (2009). Engaging Students Through Inquiry-Oriented Learning and Teaching. USA: Rowman \& Littlefield Education

Emirmustafaoğlu, A., \& Gökmen, D. U. (2015). The Effects of Picture vs. Translation Mediated Instruction on L2 Vocabulary Learning. Procedia - Social and Behavioral Sciences, 199, 357-362. https://doi.org/10.1016/j.sbspro.2015.07.559

Ghaedi, R., \& Shahrokhi, M. (2016). The Impact of Visualization and Verbalization Techniques on Vocabulary Learning of Iranian High School EFL learners: A Gender Perspective. Ampersand, 3, 32-42. https://doi.org/10.1016/j.amper.2016.03.001

Hiebert, Elfrieda H and L. Kamil. (2005). Teaching and Learning Vocabulary. Bringing Research to Practice. Mahwah New Jersey: Lawrence Erlbaum Associates.

Joan H. Lee (2011). What does txting do 2 Language: The Influences of exposure to Messaging and print media on acceptability constraints (PDF) (M. A.). University of Calgary. Retrieved 20 November 2013. Lay summary.

Joyce, B. \& Weil, M. and Calhoun, E. (2008). Models of teaching, 8th ed. Englewood Cliffs, NJ: Prentice-Hall. (there is now a 9th, 2014 edition)

Leung, L. (2015). Validity, Reliability, and Generalizability in Qualitative Research. J Family Med Prim Care. 2015 Jul-Sep; 4(3): 324-327.

Kelley, K., Clarke, B., Brown, V. and Sitzia, J. (2003). Good Practice in the Conduct and Reporting of Survey Research. International Journal for Quality in Health Care, 15, 261-266. http://dx.doi.org/10.1093/intqhc/mzg031

Nation, I. S. P. (2011). Learning Vocabulary in Another Language. Cambridge: Cambridge University Press.

Rakchanok (2014). Strategies for Dealing with Vocabulary Learning. Problems by Thai University Students. Faculty of Liberal Arts, Khon Kaen University, Nong Khai Campus, Nong Khai : Thailand 
Rupublic of Indonesia. (2013). Kurrikulum Nasional 2013. Jakarta: Kementrian Pendidikan Nasional.

Suraya, D. (2017). The Effect Of Using Picture Word Inductive Model On Teaching Descriptive Text Writing. Tanjungpura Universiry.

Tosun, S. (2015). The Effects of Blended Learning on EFL Students' Vocabulary Enhancement. Procedia - Social and Behavioral Sciences, 199, 641-647. https://doi.org/10.1016/j.sbspro.2015.07.592

Turgut, Y., \& Irgin, P. (2009). Young learners' language learning via computer games. Procedia - Social and Behavioral Sciences, 1(1), 760-764. https://doi.org/10.1016/j.sbspro.2009.01.135 